\title{
Efficacy of deep neck flexor exercise for neck pain: a randomized controlled study
}

\section{Boyun ağrısında derin boyun fleksör egzersizinin etkinliği: randomize kontrollü çalışma}

\author{
Amr Almaz Abdel-aziem, ${ }^{1}$ Amira Hussin Draz ${ }^{2}$ \\ ${ }^{1}$ Department of Biomechanics, Faculty of Physical Therapy, Cairo University, Giza, Egypt \\ ${ }^{2}$ Department of Basic Sciences, Faculty of Physical Therapy, Cairo University, Giza, Egypt
}

Received / Geliş tarihi: December 2014 Accepted / Kabul tarihi: May 2015

\begin{abstract}
Objectives: This study aims to investigate the efficacy of deep neck flexor exercises in the management of neck pain.

Patients and methods: Sixty patients with non-specific neck pain of at least six-week duration were randomized into one of three groups: group 1 - physical therapy agents including transcutaneous electrical nerve stimulation, continuous ultrasound and infra-red irradiation; group 2 - physical therapy agents + isometric, stretching, and scapulothoracic exercises; and group 3 - physical therapy agents + deep neck flexor exercise. The patients were evaluated with a visual analog scale (VAS), Neck Disability Index (NDI), and the range of motion in the three planes at baseline and after one month of treatment, and at three-month follow-up period.

Results: Compared to baseline, all groups showed a significant decrease in VAS scores at one month. However, this improvement was achieved only in group 3 at three months indicating a significant difference among the groups $(\mathrm{p}<0.05)$. During the study, the improvement in disability was significant in group 3 , as assessed by the NDI and range of motion $(\mathrm{p}<0.05)$.

Conclusion: This study demonstrates the superiority of the deep neck flexor exercise, which offers several advantages in pain, disability, and range of motion outcomes, compared to isometric, stretching, and scapulothoracic exercises in combination with physical therapy agents for the management of neck pain.
\end{abstract}

Keywords: Neck muscle; neck pain; strengthening exercise; stretching exercise.

\section{$\ddot{O} Z$}

Amaç: Bu çalışmada boyun ağrısının tedavisinde derin boyun fleksör egzersizlerinin etkinliği araştırıldı.

Hastalar ve yöntemler: En az altı hafta süreyle nonspesifik boyun ağrılı 60 hasta üç gruptan birine randomize edildi: grup 1 - transkütanöz elektriksel sinir stimülasyonu, sürekli ultrason ve kızılötesi ışını dahil fizik tedavi ilaçları; grup 2 - fizik tedavi ilaçları + izometrik, esneme ve skapulotorasik egzersizler ve grup 3 - fizik tedavi ilaçları + derin boyun fleksör egzersizi. Hastalar başlangıçta ve tedaviden bir ay sonra ve takip döneminin üçüncü ayında görsel analog ölçeği (GAÖ), Boyun Engellilik İndeksi (BEİ) ve üç düzlemde hareket açıklığ 1 ile değerlendirildi.

Bulgular: Başlangıca kıyasla, tüm gruplarda birinci ayda GAÖ skorlarında anlamlı bir düşüş izlendi. Ancak, bu iyileşme, üçüncü ayda yalnızca grup 3'te elde edildi; bu da gruplar arasında anlamlı bir farklılık olduğunu gösteriyordu ( $<<0.05)$. Çalışma sırasında engellilikte görülen iyileşme, BEİ ve hareket açıklı̆̆ı ile değerlendirildiği üzere, grup 3’te anlamlı düzeyde idi ( $<<0.05)$.

Sonuç: Bu çalışma boyun ağrısı tedavisinde fizik tedavi ile birlikte izometrik, esneme ve skapulotorasik egzersizlere kıyasla, ağrı, engellilik ve hareket açıklığı sonuçları açısından birtakım avantajlar ile derin boyun fleksör egzersizinin üstünlüğünü göstermektedir.

Anahtar sözcükler: Boyun kası; boyun ağrısi; kuvvetlendirme egzersizi; esneme egzersizi.

Corresponding author / İletişim adresi: Amr Almaz Abdel-aziem, MD. 7 Ahmed Elzaiat Street, Ben Elsaryat, EI-Dokki, Faculty of Physical Therapy, Cairo University, 12612 Giza, Egypt. e-mail / e-posta: amralmaz@yahoo.com 
The prevalence of neck pain was reported to range from $22 \%$ to $30 \%$ of the population. It is considered one of the most common pain problems. ${ }^{[1,2]}$ It is usually accompanied by a substantial negative effect on daily life that results in extensive use of healthcare resources. $^{[2,3]}$ It is important to understand which structures are capable of producing pain and disability, to improve patients' functional status and quality of life. Numerous studies have shown an association between reduction in the strength and endurance capacity of the cervical muscles and neck pain. ${ }^{[4,5]}$ There are specific muscles in the cervical spine when weakened tend to cause neck pain; the most common of these being the deep and anterior cervical flexors ${ }^{[4-6]}$ Patients with chronic, nonspecific neck pain have decreased maximal isometric strength and isometric endurance of the cervical muscles. ${ }^{[7,8]}$

The cervical segment is supported by the longus colli muscle anteriorly and the semispinalis cervicis and cervical multifidus muscles posteriorly. ${ }^{[9,10]}$ In particular, the longus colli muscle has a major postural function in supporting the cervical lordosis. ${ }^{[10]}$ In addition, the craniocervical region is supported by the longus capitis muscle anteriorly and the suboccipital extensor, semispinalis, and splenius capitis muscles posteriorly. ${ }^{[1]}$

Studies have identified impaired activation of the deep cervical flexor muscles, the longus colli and longus capitis, in people with neck pain. ${ }^{[12,13]}$ Given the role of the deep cervical flexor muscles in postural support and the knowledge of impaired activation of these muscles in people with neck pain, it is likely that this patient population also would display deficits in the postural endurance of these muscles. Indeed, people with neck pain drift into a more forward head position when distracted. ${ }^{[14]}$

Thus, exercise is one of the most frequently used modalities in the rehabilitation of subjects with neck pain to gain muscle strength, endurance, and flexibility in order to restore injured tissues, and to sustain normal life activities. ${ }^{[2]}$ Exercise programs for managing neck pain differ with regard to duration, training frequency, intensity, and mode of exercise. Previous studies have shown that isometric exercises and strength training can have positive effects on neck pain. ${ }^{[15,16]}$ On the other hand, retraining the deep cervical flexor muscles, which has been shown to decrease neck pain symptoms and increase the activation of the deep cervical flexor muscles during performance of the clinical test of craniocervical flexion, ${ }^{[17]}$ may improve the ability to maintain an upright posture of the cervical spine. In this study, we aim to investigate whether deep neck flexor (DNF) exercise is effective in the management of neck pain when this intervention is added as a supplement to physical therapy agents (PTA) or when it is compared with isometric, stretching, and scapulothoracic exercises.

\section{PATIENTS AND METHODS}

Sixty patients with neck pain with a duration of at least six weeks were recruited into the study. Neck pain was defined as non-specific neck pain without specific, identifiable etiology (i.e. infection, inflammatory disease), but which could be reproduced by neck movement or provocation tests in the location of the dorsal part of the neck in an area limited by a horizontal line through the most inferior portion of the occipital region and a horizontal line through the spinous process of the first thoracic vertebra. ${ }^{[1]}$ Patients were excluded if they had a history of cervical spine injury or surgery, if their neck pain was secondary to other conditions (including neoplasm, neurological diseases or vascular diseases), if they had a radiculopathy presenting neurological deficit or if they had infection or inflammatory arthritis in the cervical spine, if they had received physiotherapy within the six-months of the study or a poor general health status that would interfere with the exercises during the study. The patients were also excluded if they had pain with any cause in or around the scapula, shoulder, upper extremities and lumbar spine that prevents stabilization of these structures. These exclusion criteria were verified by examining medical history, physical examination and by X-ray. ${ }^{[18]}$ All procedures were approved by the Research Ethical Committee of the Faculty of Physical Therapy, Cairo University, and conducted in accordance with the Declaration of Helsinki. Written informed consent was obtained from patients who participated in this study.

The study was a randomized, single-blind, prospective study with a three-month follow-up period. After baseline characteristics (weight, height, and age) were recorded, the patients were assigned to one of the three following treatment groups on the basis of a computer-generated minimization method, ${ }^{[19]}$ taking into account subject's age, and degree of neck pain as assessed by visual analog scale (VAS): group 1: PTA; group 2: PTA + isometric, stretching of the cervical, shoulder, chest, and scapular muscles and scapulothoracic exercises; and group 3: PTA + DNF exercise. The demographic characteristics of the subjects are shown in Table 1 . 
Table 1. Demographic characteristics of subjects

\begin{tabular}{|c|c|c|c|c|}
\hline & Group $1(\mathrm{n}=20)$ & Group $2(n=20)$ & Group $3(n=20)$ & \\
\hline & Mean \pm SD & Mean \pm SD & Mean \pm SD & $p$ \\
\hline Age (years) & $48.50 \pm 7.82$ & $47.90 \pm 6.79$ & $50.10 \pm 4.71$ & 0.553 \\
\hline Height $(\mathrm{cm})$ & $172.40 \pm 5.10$ & $175.25 \pm 5.65$ & $173.80 \pm 5.88$ & 0.276 \\
\hline Weight $(\mathrm{kg})$ & $75.90 \pm 5.33$ & $77.10 \pm 5.11$ & $74.15 \pm 3.51$ & 0.148 \\
\hline
\end{tabular}

\section{Interventions}

Physical therapy agents included a combination of conventional transcutaneous electrical nerve stimulation (TENS), continuous ultrasound and infrared irradiation with the assistance of the same physiotherapist for all groups during the study. Following infrared irradiation for $20 \mathrm{~min}$ at a 40 $\mathrm{cm}$ distance for the neck region ( $\mathrm{R} \mathrm{125,} 250$ watt, Philips; 126597: Australia). Transcutaneous electrical nerve stimulation was administered at a frequency of $80 \mathrm{~Hz}$ with $10-30 \mathrm{~mA}$ intensity for 30 minutes. Four surface electrodes, $5 \times 5 \mathrm{~cm}$ each, were placed over the painful area in the neck region, ${ }^{[20]}$ TENS was delivered using Intelect Advanced (REF2773MS; Chattanooga: Mexico). The intensity of TENS was adjusted to produce a tingling sensation that was approximately 2-3 times the patient's sensory threshold. The continuous ultrasound was used with $1.5 \mathrm{~W} / \mathrm{cm}^{2}$ intensity and at a frequency of $1 \mathrm{MHz}$ over the neck area for 10 minutes, using Metron Accusonic Plus (Metron Medical, Australia Pty Ltd. Carrum Downs Victoria Australia 3201).

Deep neck flexors exercise: The patients performed deep neck flexor strengthening exercises as described by Petersen, ${ }^{[21]}$ without the use of a biofeedback unit. The patient was supine, with the cervical spine in a neutral position, and instructed to flatten the curve of the neck by nodding the head. This position was held for 10 seconds and repeated 10 times. The therapist or patient monitors the sternocleidomastoid muscles to ensure minimal to no activation of these muscles during the deep neck flexor contraction (Figure 1).

Isometric and stretching exercise: The session included 5-6 minutes jogging and 10 minutes stretching (the cervical, shoulder, chest, and scapular muscles) in the standing position, and 15 minutes of isometric exercises (cervical flexion, extension, rotation and side-bending by resisting the forehead in the seated position) for a total of 30 minutes.

Scapulothoracic exercises which include serratus anterior and both middle and lower trapezius muscle strengthening. ${ }^{[22]}$ For serratus anterior strengthening exercises, the patients should stand against the wall with the arms approximately shoulder width apart (step 1), the patient performs a "push-up with a plus" exercise by pushing away from the wall until the elbows are fully extended and the scapulae are protracted as far as possible (step 2) (Figure 2). For lower and middle trapezius strengthening exercises, from prone position, the patient should horizontally abduct the shoulder with scapular depression, adduction and upward rotation. This should be performed at approximately $120-135^{\circ}$ abduction for lower trapezius muscle re-education (Figure 3), and at approximately $90^{\circ}$ abduction for middle trapezius muscle re-education. The shoulder should be externally rotated so the thumb points up toward the ceiling and the scapula should not elevate towards the head. The patient may place his head and neck in any comfortable posture. If the patient is unable to rotate the neck, he must put a pillow under the upper chest and keep the neck in neutral position, with the forehead resting on the patient's opposite forearm or a small towel roll. All exercises were conducted under the guidance of the same physiotherapist.

At each visit during the study, the patients were instructed to perform their exercises regularly. All patients were instructed to perform the exercises at home, twice daily. The duration of physical therapy

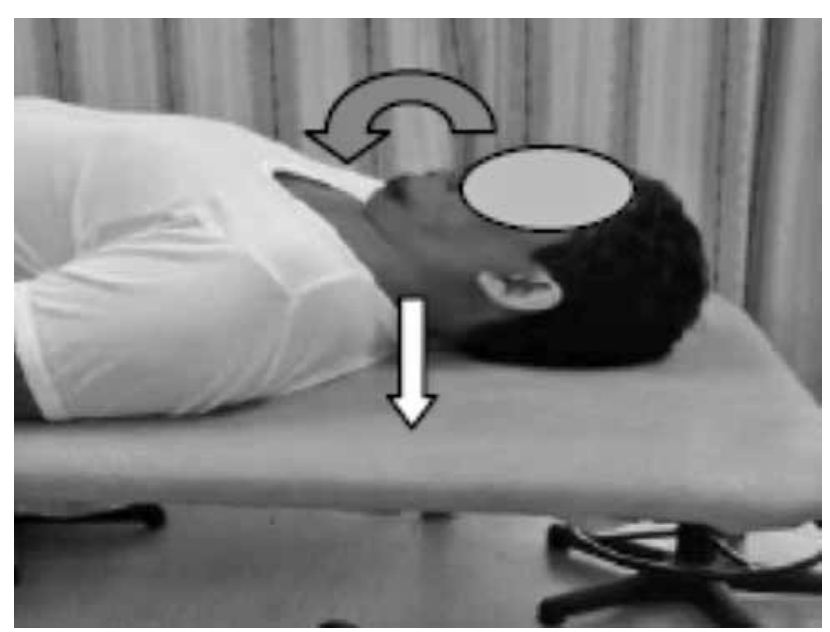

Figure 1. Deep neck flexors strengthening exercises. 

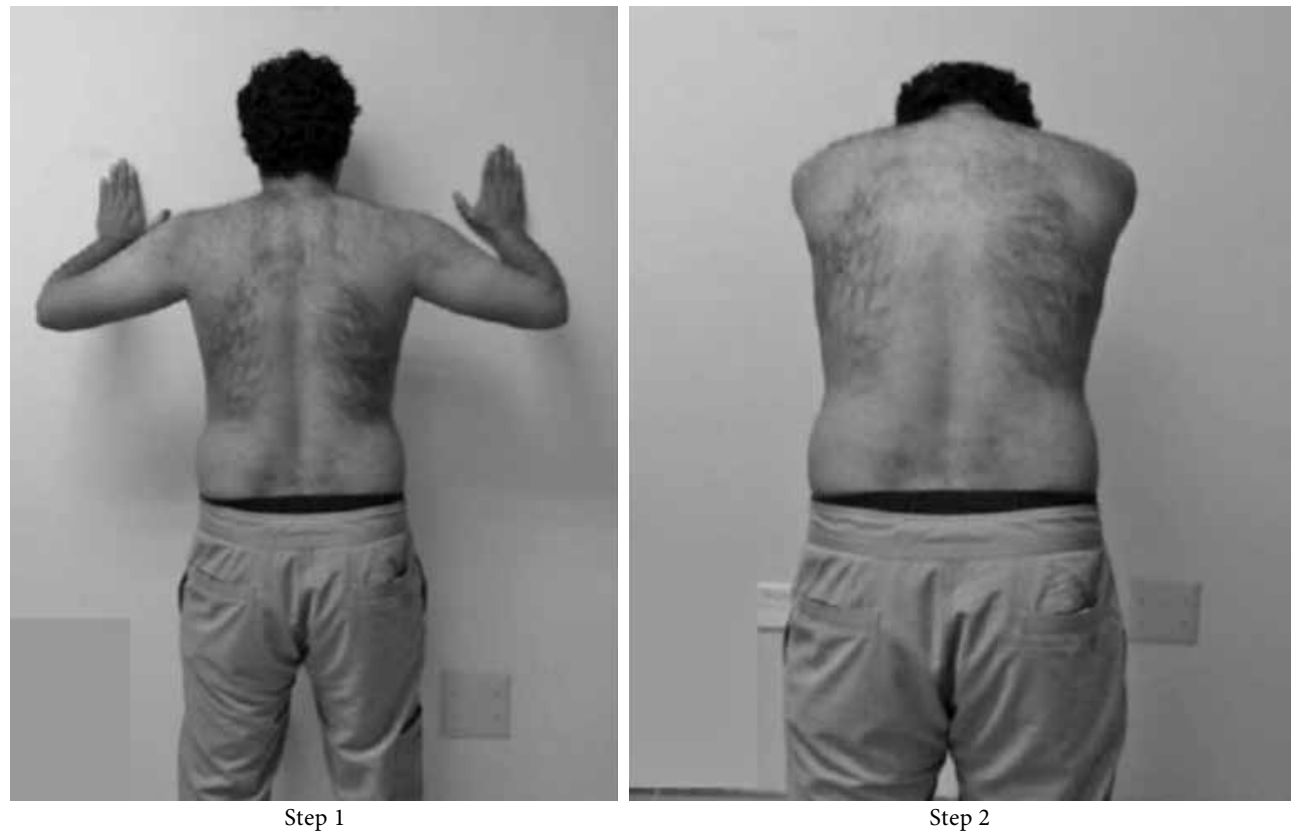

Figure 2. Serratus anterior strengthening exercises.

intervention was four weeks (five days each week). At the initial treatment visit, each patient was educated on the importance of correct postural alignment of the spine during sitting and standing activities. If the patient changes his position often, this will keep stress and strain from his neck and upper back.

\section{Assessment}

Clinical assessments were made at baseline and at months one and three. Pain was assessed using the following parameters; a $10 \mathrm{~cm}$ VAS (the patients used the VAS to make an assessment of their own pain, with 0 representing no pain, and $10 \mathrm{~cm}$ representing severe pain). ${ }^{[23]}$ The use of non-steroidal anti-inflammatory drugs (NSAIDs) was not permitted during the study period; any pre-treatment with NSAIDs had to be

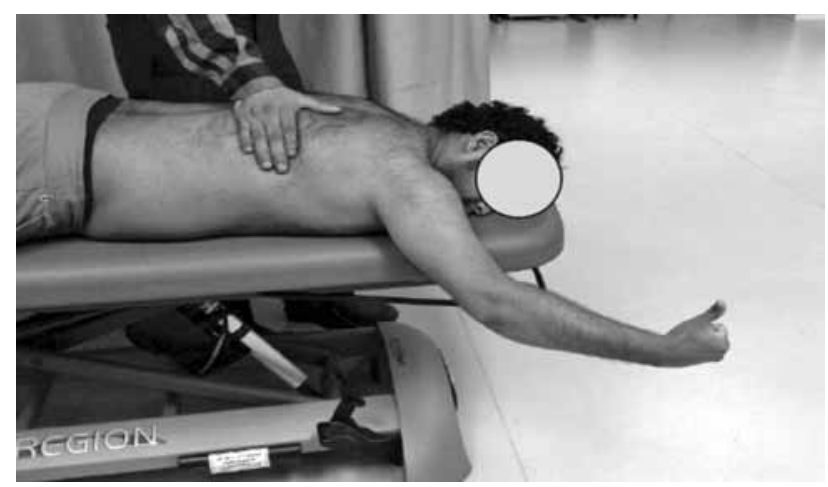

Figure 3. Trapezius strengthening exercises. discontinued seven days prior to the start of the study. If the patient required additional analgesic medication because of neck pain during the study, treatment with simple analgesic (paracetamol, maximum of 500 to $1000 \mathrm{mg}$ daily) was permitted.

Disability was assessed using the Neck Disability Index (NDI). ${ }^{[24]}$ At the same time, active range of motion (ROM) of the cervical spine in three planes was measured with universal goniometry (UG) with a double-armed full-circle protractor made of transparent plastic (Benchmark Medical, Inc. Malvern, PA, USA) as a reliable method when the same therapist takes the measurements ${ }^{[25]}$ for all patients. The length of the arms was $30 \mathrm{~cm}$ (12 inches) and the scale of the protractor was marked in $1^{\circ}$ increments.

The participants' position and placement of the UG were standardized. All subjects sat in a standard metal-frame chair so that their thoracic spine maintained contact with the chair's backrest and their lumbosacral spine filled the gap between the seat and the backrest. Their feet were positioned flat on the floor and their arms rested freely at their sides. As instructed by the examiner, each subject performed three repetitions of neck active ROM (warm-ups) in each direction within a designated cardinal plane to increase compliance of the neck's soft tissues. ${ }^{[25]}$ All assessments were recorded by the same blinded examiner. ${ }^{[18]}$ 
For measuring cervical flexion and extension, the starting position for both cervical flexion and extension was assumed after the examiner manually adjusted the subject's neck so that the external acoustic meatus-to-base of nares reference line was parallel to the floor. The UG's axis was centered over the external acoustic meatus; the fixed arm was held vertical, while the movable arm was aligned with the meatus-to-base of nares reference line as the subject actively flexed and extended the neck.

For measuring cervical lateral flexion, each subject bent his or her head and cervical spine first left and then right without elevating his or her shoulder. The examiner aligned the fixed arm of the UG parallel with a horizontal reference line between the patient's sternal notch and acromion process; the movable arm was aligned with the midline of the patient's nose. The starting or neutral position was with the arms of the UG perpendicular.

For measuring cervical rotation, each subject rotated his or her head first left and then right. The UG axis was centered on the top of the subject's head; the fixed arm was aligned parallel to an imaginary line between the subject's acromion processes, and the movable arm was aligned with the subject's nose. The examiner wrote down both start and end points of the cervical active ROM for the three planes of motion. The placement procedure for the UG for measuring the ROM of the cervical spine in three planes has been described by Youdas et al. ${ }^{[25]}$

\section{Statistical analysis}

Data was analyzed using a SPSS version 16.0 software (SPSS Inc., Chicago, IL, USA). Treatment groups were compared by one-way analysis of variance (ANOVA). Repeated ANOVA measurements were used to evaluate the clinical assessment parameters over the time of observation. Bonferroni test as a post hoc test was used to determine the change between groups when indicated. The level of significance for all tests was set at 0.05 .

\section{RESULTS}

Sixty patients were divided into three equal groups. There was no significant difference between the groups in terms of age, height, and weight $(\mathrm{p}=0.553, \mathrm{p}=0.276$, $\mathrm{p}=0.148$ ), respectively.

For VAS there was no difference between prevalues of the three groups $(\mathrm{p}=0.396)$. Compared with baseline, a significant decrease of VAS score in all groups after one-month of treatment, this decline was maintained only in group 3 at three-months follow-up $(\mathrm{p}=0.001)$. After one-month of treatment, the decrease in VAS score of group 2 and 3 were significantly lower than group $1 \quad(\mathrm{p}=0.001)$, without significant differences between group 2 and $3(\mathrm{p}=0.191)$. However, at three-months follow-up, the VAS score of group 2 and 3 were significantly lower than group $1(\mathrm{p}=0.001)$, with the VAS score of group 3 was significantly lower than group $2(\mathrm{p}=0.002)$.

For NDI there was no difference between prevalues of the three groups ( $p=0.957)$. Compared with baseline, a significant decrease of NDI score in all groups after one-month of treatment, this decline was maintained only in group 3 at three-month follow-up $(p=0.001)$. After one-month of treatment the NDI score of group 3 was significantly lower than group 1 and 2 $(\mathrm{p}=0.001, \mathrm{p}=0.030)$, respectively, without significant difference between group 1 and $2(\mathrm{p}=0.259)$. Moreover, at three-month follow-up the NDI score of group 3 was significantly lower than group 1 and $2(p=0.001)$, without significant differences between group 1 and 2 $(\mathrm{p}=0.629)$, as shown in Table 2 .

Table 3 shows the ROM measurements. For sagittal and transverse ROM there was no significant

Table 2. The values of visual analog scale and neck disability index at baseline, one-month, and three-month follow-up

\begin{tabular}{|c|c|c|c|c|}
\hline & Group $1(n=20)$ & Group $2(n=20)$ & Group $3(n=20)$ & \\
\hline & Mean \pm SD & Mean \pm SD & Mean \pm SD & $p$ \\
\hline \multicolumn{5}{|c|}{ Visual analog scale } \\
\hline At baseline & $6.85 \pm 1.09$ & $6.40 \pm 1.10$ & $6.70 \pm 0.98$ & 0.396 \\
\hline 1 month & $5.30 \pm 1.22$ & $3.85 \pm 1.09$ & $3.35 \pm 1.27$ & 0.001 \\
\hline 3 month & $5.65 \pm 1.57$ & $4.10 \pm 1.21$ & $2.75 \pm 1.02$ & 0.001 \\
\hline \multicolumn{5}{|c|}{ Neck disability index } \\
\hline At baseline & $19.20 \pm 5.20$ & $19.45 \pm 6.19$ & $19.70 \pm 4.43$ & 0.957 \\
\hline 1 month & $15.90 \pm 5.62$ & $13.85 \pm 7.17$ & $9.85 \pm 3.75$ & 0.005 \\
\hline 3 month & $18.10 \pm 5.23$ & $18.90 \pm 6.04$ & $9.45 \pm 4.16$ & 0.001 \\
\hline
\end{tabular}


Table 3. The patients' range of motion in three planes at baseline, one-month, and threemonth follow-up

\begin{tabular}{|c|c|c|c|c|}
\hline & Group $1(\mathrm{n}=20)$ & Group $2(\mathrm{n}=20)$ & Group $3(n=20)$ & \\
\hline & Mean \pm SD & Mean \pm SD & Mean \pm SD & $p$ \\
\hline \multicolumn{5}{|l|}{ Sagittal plane } \\
\hline At baseline & $94.75 \pm 12.88$ & $98.5 \pm 10.75$ & $93.8 \pm 12.05$ & 0.425 \\
\hline 1 month & $102.15 \pm 13.93$ & $114.90 \pm 9.30$ & $112.35 \pm 11.36$ & 0.001 \\
\hline 3 month & $100.85 \pm 10.68$ & $113.35 \pm 8.98$ & $114.40 \pm 11.28$ & 0.001 \\
\hline \multicolumn{5}{|l|}{ Frontal plane } \\
\hline At baseline & $59.20 \pm 10.42$ & $57.65 \pm 8.69$ & $62.10 \pm 10.45$ & 0.359 \\
\hline 1 month & $64.40 \pm 8.64$ & $72.60 \pm 10.19$ & $70.75 \pm 8.78$ & 0.018 \\
\hline 3 month & $62.45 \pm 9.43$ & $69.65 \pm 8.58$ & $75.60 \pm 8.83$ & 0.001 \\
\hline \multicolumn{5}{|c|}{ Transverse plane } \\
\hline At baseline & $102.65 \pm 11.16$ & $103.95 \pm 13.17$ & $104.50 \pm 9.44$ & 0.870 \\
\hline 1 month & $115.15 \pm 15.63$ & $132.80 \pm 11.27$ & $131.6 \pm 11.04$ & 0.001 \\
\hline 3 month & $117.2 \pm 14.94$ & $127.45 \pm 11.27$ & $134.55 \pm 11.22$ & 0.001 \\
\hline
\end{tabular}

difference between pre-values of the three groups $(p=0.425, p=0.870)$, respectively. There was significant increase in ROM after one-month of treatment and at three-month follow-up for all groups $(\mathrm{p}=0.001)$. After one-month of treatment, and at three-month follow-up the improvement of group 2 and 3 were significantly higher than group $1(\mathrm{p}=0.001)$, without significant difference between group 2 and $3(p=0.616, p=0.577$, $\mathrm{p}=0.768$, and $\mathrm{p}=0.080)$, respectively.

For the ROM in the frontal plane, there was no significant difference between pre values of the three groups $(p=0.359$ ). There were significant improvement after one-month of treatment in all groups, this improvement was maintained only in group 3 at three-month follow-up $(\mathrm{p}=0.001)$. After one-month of treatment, the improvement of group 2 and 3 were significantly higher than group $1(\mathrm{p}=0.018)$, without significant differences between group 2 and $3(\mathrm{p}=0.529)$. However, at three-month follow-up, the improvement of group 2 and 3 were significantly higher than group $1(\mathrm{p}=0.001)$, with the improvement of group 3 was significantly higher than group $2(\mathrm{p}=0.040)$.

\section{DISCUSSION}

This study demonstrated the efficacy of DCF exercise in the management of neck pain when this intervention is used as a supplement to PTA or is compared with isometric, stretching, and scapulothoracic exercises. The results showed that, while pain significantly decreased in all treatment groups after one-month of treatment, this improvement was maintained throughout the follow-up after threemonths only in those patients treated with DCF exercise in addition to PTA. Moreover, compared with other groups, the improvement in disability assessment parameter in the DCF exercise group was also indicative of the effectiveness of DCF exercise in the management of neck pain.

Lluch et al. ${ }^{[26]}$ showed the effectiveness of DCF exercise in improving neck pain and disability in patients with chronic neck pain. Moreover, this patient with chronic neck pain due to prolonged immobilization responded positively to DCF training, resulting in an increase in cervical spine range of motion and a reduction of dizziness, pain, and limitations in activities. ${ }^{[27]}$

Recently, Falla et al. ${ }^{[28]}$ explained the reasons why DCF exercise is effective in improving neck pain and function, they found that specific training of the deep cervical flexor muscles in women with chronic neck pain reduces pain and improves the activation of these muscles, especially in those with the least activation of their deep cervical flexors before training. This finding suggests that the selection of exercise based on a precise assessment of the patients' neuromuscular control and targeted exercise interventions based on this assessment are likely to be the most beneficial to patients with neck pain.

Sihawong et al. ${ }^{[29]}$ evaluated the effects of an exercise program focusing on muscle stretching and endurance training on the 12 -month incidence rate of neck pain in office workers. They found that there was no significant difference in pain intensity, disability and quality of life and health status between the intervention and control groups. This was against the findings of the current study. However, exercise programs that aim to enhance motor control of the cervical spine improve the specificity of neck muscle 
activity and reduce pain and disability in patients with neck pain. ${ }^{[30]}$

Moreover, Dusunceli et al. ${ }^{[18]}$ found that PTA combined with isometric and stretching exercises is more effective than PTA alone in reducing pain, improving neck mobility and increasing neck range of motion. However, their study demonstrates the superiority of the neck stabilization exercises, with some advantages in the pain and disability outcomes, compared with isometric and stretching exercises in combination with physical therapy agents for the management of neck pain.

The DCF exercises directly activate the deep cervical flexor musculature, ${ }^{[31,32]}$ which have a relatively high density of muscle spindles. ${ }^{[9]}$ Improved cervical kinesthetic sense following DCF training ${ }^{[33]}$ also may explain the higher improvement of neck stability in the third group. Moreover, the forward head position of subjects with chronic neck pain ${ }^{[14]}$ has been associated with compressive loading of the cervical tissues ${ }^{[34,35]}$ The improved cervical posture created through DCF exercise, may have an additional long-term benefit of reducing recurrent episodes of neck pain. ${ }^{[36]}$

Jull et al. ${ }^{[37]}$ studied the coordination between the deep and superficial cervical flexor muscles in a low load cranio-cervical flexion (C-CF) task. The results revealed increased electromyographic amplitude of the large superficial sternocleidomastoid, and anterior scalene muscles in patients with neck pain. This was associated with reduced activation of the DCF muscles, and reduced range of C-CF motion to perform the task. ${ }^{[13]}$ So, Jull et al ${ }^{[38]}$ compared the physiological effects of low load C-CF exercise and neck flexor strengthening to evaluate effects on deep and superficial cervical muscle activity during the C-CF test. Their study showed that activation of the DCF was increased at each of the five levels of the C-CF test and activity of the sternocleidomastoid and anterior scalene muscles were reduced following $\mathrm{C}-\mathrm{CF}$ training. This supports the results of the current study.

The DCF exercises combined with PTA had advantages over the isometric, stretching, and scapulothoracic exercises combined with PTA or PTA alone, for the results of the NDI in the three-month follow-up period, suggesting that DCF exercises may be more effective in improving neck disability. Since disability is usually accompanied by a substantial effect on daily life, resulting in an extensive use of healthcare resources, ${ }^{[2,3]}$ to improve the patient's disability or enable them to return to normal activity is the main aim of any treatment approach. With regard to the results of the present study, DCF exercises combined with PTA may be a better approach for meeting this aim.

The results of the active ROM of the cervical spine showed that only the DCF exercises combined with PTA group achieved a significant increase in the three plane measurements during the follow-up especially the frontal plane ROM. On the other hand, the exercises combined with PTA group showed a significant increase in the sagittal plane and transverse plane ROMs at three-month follow-up, while no significant improvement was observed in PTA alone group at three-month follow-up. Even though some studies have found no correlation between ROM and symptomatic improvement in any of the treatment groups. ${ }^{[6,39]}$

Moreover, Howell ${ }^{[40]}$ deducted the need for further research to explore the association between the NDI, neck pain and cervical ranges of motion. The current study proved that the reduction of neck pain, and improvement of neck stability was associated with improvement in ROM in the three planes of movement especially for the DCF exercises combined with PTA group.

There are some limitations of this study. First, the small number of cases recruited. Second, because there was no group consisting of DCF exercise alone, we cannot conclude whether DCF exercise without PTA has similar effects on improvement in neck pain. Although there were significant differences between the groups treated with DCF exercise + PTA, exercise + PTA or PTA alone in our study, further controlled studies of DCF exercise without PTA on large populations are required in order to establish its definitive effectiveness. Moreover, future work will be needed to include electromyography studies to record the effect of additional DCF exercise training on muscular activities in those patients with neck pain. Third, the gender in this study was limited to males only. Thus, the appropriateness of generalizing the results is confined to this specific population. Fourth, the lack of a strictly recorded, dose-specific home-exercise program maintained during the course of treatment. Lastly, the effect of the rehabilitation program on the participants' psychological parameters such as quality of life was not examined.

In conclusion, this study shows that a combination treatment of DCF exercise + PTA is the most effective 
intervention for the management of neck pain, with some advantages in pain, disability, and ROM over the combination of isometric, stretching, and scapulothoracic exercises + PTA, or PTA alone.

\section{Acknowledgement}

The authors gratefully acknowledge Faris Al Thobaiti, student of physical therapy, for drawing the exercises figures.

\section{Declaration of conflicting interests}

The authors declared no conflicts of interest with respect to the authorship and/or publication of this article.

\section{Funding}

The authors received no financial support for the research and/or authorship of this article.

\section{REFERENCES}

1. Bovim G, Schrader H, Sand T. Neck pain in the general population. Spine (Phila Pa 1976) 1994;19:1307-9.

2. Wolsko PM, Eisenberg DM, Davis RB, Kessler R, Phillips RS. Patterns and perceptions of care for treatment of back and neck pain: results of a national survey. Spine (Phila $\mathrm{Pa}$ 1976) 2003;28:292-7.

3. Boden SD, Swanson AL. An assessment of the early management of spine problems and appropriateness of diagnostic imaging utilization. Phys Med Rehabil Clin N Am 1998;9:411-7.

4. Chiu TT, Sing KL. Evaluation of cervical range of motion and isometric neck muscle strength: reliability and validity. Clin Rehabil 2002;16:851-8.

5. Ylinen J, Salo P, Nykänen M, Kautiainen H, Häkkinen A. Decreased isometric neck strength in women with chronic neck pain and the repeatability of neck strength measurements. Arch Phys Med Rehabil 2004;85:1303-8.

6. Gogia PP, Sabbahi MA. Electromyographic analysis of neck muscle fatigue in patients with osteoarthritis of the cervical spine. Spine (Phila Pa 1976) 1994;19:502-6.

7. Silverman JL, Rodriquez AA, Agre JC. Quantitative cervical flexor strength in healthy subjects and in subjects with mechanical neck pain. Arch Phys Med Rehabil 1991;72:679-81.

8. Ylinen J, Takala EP, Nykänen M, Häkkinen A, Mälkiä E, Pohjolainen T, et al. Active neck muscle training in the treatment of chronic neck pain in women: a randomized controlled trial. JAMA 2003;289:2509-16.

9. Boyd-Clark LC, Briggs CA, Galea MP. Muscle spindle distribution, morphology, and density in longus colli and multifidus muscles of the cervical spine. Spine (Phila $\mathrm{Pa}$ 1976) 2002;27:694-701.

10. Conley MS, Meyer RA, Bloomberg JJ, Feeback DL, Dudley GA. Noninvasive analysis of human neck muscle function. Spine (Phila Pa 1976) 1995;20:2505-12.

11. Kettler A, Hartwig E, Schultheiss M, Claes L, Wilke HJ. Mechanically simulated muscle forces strongly stabilize intact and injured upper cervical spine specimens. J Biomech 2002;35:339-46.
12. Falla DL, Jull GA, Hodges PW. Patients with neck pain demonstrate reduced electromyographic activity of the deep cervical flexor muscles during performance of the craniocervical flexion test. Spine (Phila Pa 1976) 2004;29:2108-14.

13. Falla D, Jull G, Hodges PW. Feedforward activity of the cervical flexor muscles during voluntary arm movements is delayed in chronic neck pain. Exp Brain Res 2004;157:43-8.

14. Szeto GP, Straker LM, O'Sullivan PB. A comparison of symptomatic and asymptomatic office workers performing monotonous keyboard work--2: neck and shoulder kinematics. Man Ther 2005;10:281-91.

15. Chiu TT, Lam TH, Hedley AJ. A randomized controlled trial on the efficacy of exercise for patients with chronic neck pain. Spine (Phila Pa 1976) 2005;30:1-7.

16. Andersen LL, Kjaer M, Søgaard K, Hansen L, Kryger AI, Sjøgaard G. Effect of two contrasting types of physical exercise on chronic neck muscle pain. Arthritis Rheum 2008;59:84-91.

17. Falla D, Jull G, Hodges P. Training the cervical muscles with prescribed motor tasks does not change muscle activation during a functional activity. Man Ther 2008;13:507-12.

18. Dusunceli Y, Ozturk C, Atamaz F, Hepguler S, Durmaz B. Efficacy of neck stabilization exercises for neck pain: a randomized controlled study. J Rehabil Med 2009;41:626-31.

19. Mealy K, Brennan H, Fenelon GC. Early mobilization of acute whiplash injuries. Br Med J (Clin Res Ed) 1986;292:656-7.

20. Basford JR. Physical agents. In: DeLisa JA, Gans BM, editors. Rehabilitation medicine: principles and practice. 3rd ed. Philadelphia: Lippincott-Raven Publishers; 1998. p. 483-503.

21. Petersen SM. Articular and muscular impairments in cervicogenic headache: a case report. J Orthop Sports Phys Ther 2003;33:21-30.

22. Flynn TW, Whitman JM, Magel J. Orthopaedic manual physical therapy management of the cervical-thoracic spine and ribcage. Fort Collins: Manipulations, Inc.; 2000.

23. Carlsson AM. Assessment of chronic pain. I. Aspects of the reliability and validity of the visual analogue scale. Pain 1983;16:87-101.

24. Kose G, Hepguler S, Atamaz F, Oder G. A comparison of four disability scales for Turkish patients with neck pain. J Rehabil Med 2007;39:358-62.

25. Youdas JW, Carey JR, Garrett TR. Reliability of measurements of cervical spine range of motion-comparison of three methods. Phys Ther 1991;71:98-104.

26. Lluch E, Arguisuelas MD, Coloma PS, Palma F, Rey A, Falla D. Effects of deep cervical flexor training on pressure pain thresholds over myofascial trigger points in patients with chronic neck pain. J Manipulative Physiol Ther 2013;36:604-11.

27. Thoomes-de Graaf M, Schmitt MS. The effect of training the deep cervical flexors on neck pain, neck mobility, and dizziness in a patient with chronic nonspecific neck pain after prolonged bed rest: a case report. J Orthop Sports Phys Ther 2012;42:853-60.

28. Falla D, O'Leary S, Farina D, Jull G. The change in deep cervical flexor activity after training is associated with the degree of pain reduction in patients with chronic neck pain. Clin J Pain 2012;28:628-34. 
29. Sihawong R, Janwantanakul P, Jiamjarasrangsi W. Effects of an exercise programme on preventing neck pain among office workers: a 12-month cluster-randomised controlled trial. Occup Environ Med 2014;71:63-70.

30. Falla D, Lindstrøm R, Rechter L, Boudreau S, Petzke F. Effectiveness of an 8-week exercise programme on pain and specificity of neck muscle activity in patients with chronic neck pain: a randomized controlled study. Eur J Pain 2013;17:1517-28.

31. Falla D, Jull G, Dall'Alba P, Rainoldi A, Merletti R. An electromyographic analysis of the deep cervical flexor muscles in performance of craniocervical flexion. Phys Ther 2003;83:899-906.

32. Falla D, Bilenkij G, Jull G. Patients with chronic neck pain demonstrate altered patterns of muscle activation during performance of a functional upper limb task. Spine (Phila Pa 1976) 2004;29:1436-40.

33. Jull G, Falla D, Treleaven J, Hodges P, Vicenzino B. Retraining cervical joint position sense: the effect of two exercise regimes. J Orthop Res 2007;25:404-12.

34. Harms-Ringdahl K, Ekholm J, Schüldt K, Németh G, Arborelius UP. Load moments and myoelectric activity when the cervical spine is held in full flexion and extension. Ergonomics 1986;29:1539-52.

35. Twomey L, Taylor J. Flexion creep deformation and hysteresis in the lumbar vertebral column. Spine (Phila $\mathrm{Pa}$ 1976) 1982;7:116-22.

36. Falla D, Jull G, Russell T, Vicenzino B, Hodges P. Effect of neck exercise on sitting posture in patients with chronic neck pain. Effect of neck exercise on sitting posture in patients with chronic neck pain. Phys Ther 2007;87:408-17.

37. Jull G, Kristjansson E, Dall'Alba P. Impairment in the cervical flexors: a comparison of whiplash and insidious onset neck pain patients. Man Ther 2004;9:89-94.

38. Jull GA, Falla D, Vicenzino B, Hodges PW. The effect of therapeutic exercise on activation of the deep cervical flexor muscles in people with chronic neck pain. Man Ther 2009;14:696-701.

39. Sluijs EM, Kok GJ, van der Zee J. Correlates of exercise compliance in physical therapy. Phys Ther 1993;73:771-82.

40. Howell ER. The association between neck pain, the Neck Disability Index and cervical ranges of motion: a narrative review. J Can Chiropr Assoc 2011;55:211-21. 